\title{
Projection of Morbidity 2030 and 2050: Impact for the National Health System and Blood Supply
}

\author{
Alexander Katalinic $^{\mathrm{a}} \quad$ Elke Peters $^{\mathrm{a}} \quad$ Fritz Beske $^{\mathrm{b}} \quad$ Ron Pritzkuleit $^{\mathrm{a}}$ \\ a Institute for Cancer Epidemiology, University of Lübeck, \\ ${ }^{\mathrm{b}}$ Institute for Health Systems Research Kiel, Germany
}

\section{Keywords}

Demographic change - Projection 2050 .

Incidence $\cdot$ Prevalence

\section{Summary}

Background: The German population will decrease by $16 \%$ until 2050 , and the ratio of young to old people is shifting towards the elderly. Because risk of disease rises with age, an aging society will be confronted with a higher burden of diseases. Methods: A projection of status quo case numbers and crude rates of selected diseases was done for the years 2030 and 2050. Actual sexand age-specific rates were transferred to the predicted population figures (11th coordinated population prediction). Results: Cancer incidence will rise from 461,000 (2007) to 588,000 cases (2050) (+27\%). Crude incidence rate will increase by $52 \%$. Number of femoral neck fractures will rise by $88 \%$ (rate $+122 \%$ ). For other diseases incidence and prevalence will increase up to $144 \%$. Conclusion: Blood (products) will be necessary for the therapy of many of the presented diseases. Therefore, it can be assumed that future demand of blood will rise in a similar manner as the rising number of diseases. The projected developments describe an extraordinary challenge for the German health care system and in particular for transfusion medicine. It is necessary to develop new concepts to meet this future demands and to ensure a high-performance health care system.

\section{Introduction}

Questions about future requirements of the German health care system are discussed more and more in view of the ongoing demographic change. Until the year 2050 the German

\author{
Schlüsselwörter \\ Demographische Veränderung · Projektion 2050 . \\ Inzidenz · Prävalenz
}

\section{Zusammenfassung}

Hintergrund: Die deutsche Bevölkerung wird bis 2050 um zirka $16 \%$ sinken. Der Anteil der ältern Bevölkerung wird dabei erheblich steigen. Da mit höherem Alter auch das Erkrankungsrisiko steigt, wird eine alternde Bevölkerung mit einer höheren Krankheitslast konfrontiert. Methoden: Die Erkrankungszahlen und die rohen Raten ausgewählter Erkrankungen wurden für die Jahre 2030 und 2050 projiziert. Dazu wurden alters- und geschlechtspezifische Raten auf die vorausberechnete Bevölkerung (11. koordinierte Bevölkerungsvorausberechnung) übertragen. Ergebnisse: Die Krebsinzidenz wird von 461000 (2007) auf 588000 Fälle (2050) (+27\%) steigen. Die rohe Rate steigt dabei um 52\%. Die Zahl der Oberschenkelhalsbrüche wird um 88\% (Rate +122\%) steigen. Für andere dargestellte Erkrankungen steigen Inzidenz oder Prävalenz um bis zu 144\%. Schlussfolgerung: Für die Therapie vieler hier präsentierter Erkrankungen werden Blut oder Blutprodukte benötigt, so dass man von einem wachsenden Bedarf auf dem Steigerungsniveau der präsentierten Krankheiten ausgehen kann. Die projizierten Entwicklungen beschreiben große Herausforderungen für das deutsche Gesundheitssystem und die Transfusionsmedizin. Die Entwicklung neuer Konzepte zur Deckung des zukünftigen Bedarfs und zur Sicherung der hohen Standards im deutschen Gesundheitssystem ist notwendig.

population will decrease by about $16.3 \%$ to 68.8 million inhabitants compared to the year 2007 with a population of 82.2 million [1]. Within this period a shift in the population's age distribution will be observed, with a growing proportion of old and very old people and a continuous decrease of the pro-

\section{KARGER}

Fax +497614520714

Information@Karger.de

www.karger.com (c) 2010 S. Karger GmbH, Freiburg

Accessible online at:

www.karger.com/tmh
Prof. Dr. med. Alexander Katalinic

Institute for Cancer Epidemiology, University of Lübeck

Ratzeburger Allee 160, 23538 Lübeck, Germany

alexander.katalinic@uk-sh.de 
portion of young people. While only $2 \%$ of the German population were older than 80 years in the year 1970, this proportion will rise to $5 \%$ in the year 2010 and to about $15 \%$ in the year 2050. Thus there will be about 10.0 million Germans older than 80 years, which will equal every 7 th inhabitant.

Three points can be identified as the main causes for the demographic change of the German population:

i) Increasing life expectancy: The mean life expectancy in Germany has increased since 1960 by about $15 \%$ [2]. Actually it is about 76.9 years for men and 82.3 years for women [3]; until 2050 it is expected to increase up to 83.5 years for men and up to 88.0 years for women [1]. However, not only the life expectancy at birth has increased substantially in the last decades, but also the further life expectancy at a given age has risen.

ii) Low birth rate: Since 1975 the birth rate in Germany is nearly constant at 1.4 children per woman, which is much lower than the replacement level of 2.1 which is needed for a numerically constant population.

iii) The 'Baby Boomer' generation: Between 1955 and 1970 the birth rate was extremely high in Germany (2-2.5 children per woman), resulting in a temporarily overproportionally crowded birth cohort. This cohort will soon enter the upper age classes, resulting in high proportion of older people in the population until 2050.

Considering this, the proportion of older people will dramatically increase compared to the younger ones (fig. 1). The probability of becoming ill will usually increase exponentially with growing age $[4,5]$. These circumstances will lead to rising numbers of diseases, especially of chronic and degenerative conditions. Furthermore, age-depending events such as heart attack, stroke or types of accidents (e.g. femoral neck fracture) are expected to be more frequent in the future as well as increasing multi-morbidity. About every 6th man and every 4th woman in Germany in the age group 60-79 years has five or more different diseases [6].

A health care system that is orientated on future demands has to consider such demographic changes. Also the future development of health costs has to be kept in mind. German health cost statistics report an amount of EUR 17 billion for the age group under 15 years and EUR 111 billion for the population older than 65 years. This means that recently about $47 \%$ of the total health costs (in total EUR 236 billion) are spent for older people in Germany. About EUR 60 billion, more than half of the health costs for older people, are caused by four disease groups only (cardiovascular diseases, musculoskeletal disorders, mental and behavior disorders, diseases of the digestive system) [7].

The aim of this paper is a projection of incidence and/or prevalence of selected common diseases using a status quo scenario based on representative population-based disease rates and the officially predicted demographic population development. These numbers are helpful to assess future burdens of the health care system. A focus in this paper is set on diseases which might be associated with the needs of a highquality transfusion medicine. It will be discussed which consequences the demographic change could have on future demands of blood transfusions.

\section{Material and Methods}

A primary systematic literature search was performed with the aim to identify publications with already published disease projections for the year 2030 or 2050. Using PubMed (www.pubmed.gov) and Google Scholar Search (scholar.google.de) with search terms 'Projection' or 'Prognosis', '2030' or '2050', 'Germany' and an adequate mesh term for the selected diseases only a few $(\mathrm{n}<20)$ adequate publications were found. So in the next step a wider systematic search (including hand search) for disease frequencies was necessary to assess population-based, age- and sex-specific disease rates for the German population. We extracted incidence data (new cases (per year)) and prevalence data (number of persons alive with a disease at a certain time). For some diseases, such as diabetes, data was not always consistent due to different disease definitions, usage of different diagnostic methods etc. In these cases we tried to select the most reliable and most conservative data. Used data sources are given in tables 1 and 2.

The identified disease rates were projected by age and sex to the predicted population. We used the 11th coordinated population estimate provided by the German Federal Statistics Office (estimation 'Alternative1-W1': birth rate 1.4 children per woman, moderate increase in life
Fig. 1. Age distribution in the German population - age groups per 100 inhabitants (data before 1990 = former Federal German Republic).

\begin{tabular}{|c|c|}
\hline 1970 & 1985 \\
\hline 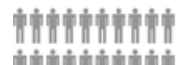 & nomenton \\
\hline 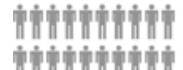 & \\
\hline & minthenth \\
\hline 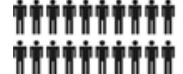 & Hintinin \\
\hline 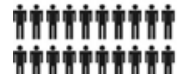 & 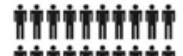 \\
\hline & 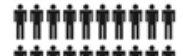 \\
\hline 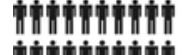 & 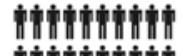 \\
\hline 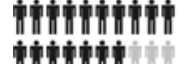 & Henthinthi \\
\hline & 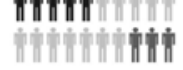 \\
\hline
\end{tabular}

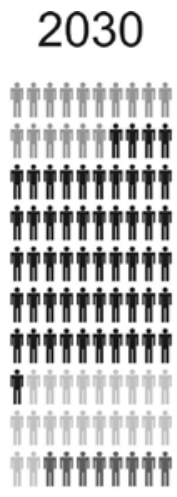

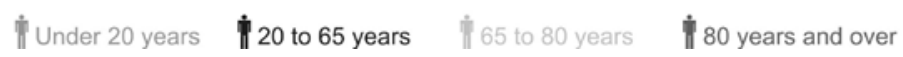

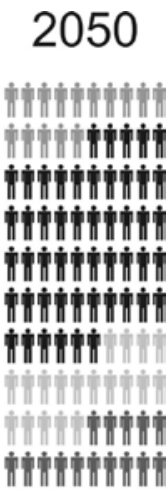


Table 1. Prevalence of selected diagnoses in Germany 2007,2030 und $2050^{\mathrm{a}}$

\begin{tabular}{|c|c|c|c|c|c|c|}
\hline \multirow[t]{2}{*}{ Diagnosis } & \multicolumn{3}{|c|}{ Absolute numbers (rounded) } & \multicolumn{3}{|c|}{ Relative numbers (per 100,000) } \\
\hline & $2007^{\mathrm{b}}$ & 2030 & 2050 & 2007 & 2030 & 2050 \\
\hline Age-dependent macula degeneration $[10]^{c}$ & 875,000 & $\begin{array}{l}1,300,000 \\
(+46 \%)\end{array}$ & $\begin{array}{l}1,800,000 \\
(+102 \%)\end{array}$ & 1,065 & $\begin{array}{l}1,660 \\
(+56 \%)\end{array}$ & $\begin{array}{l}2,574 \\
(+142 \%)\end{array}$ \\
\hline Osteoporosis $[11]^{c}$ & $8,300,000$ & $\begin{array}{l}10,200,000 \\
(+23 \%)\end{array}$ & $\begin{array}{l}10,400,000 \\
(+26 \%)\end{array}$ & 10,068 & $\begin{array}{l}13,209 \\
(+31 \%)\end{array}$ & $\begin{array}{l}15,131 \\
(+50 \%)\end{array}$ \\
\hline Arthritis $\left[12^{\mathrm{c}}\right.$ & $13,600,000$ & $\begin{array}{l}15,600,000 \\
(+15 \%)\end{array}$ & $\begin{array}{l}14,900,000 \\
(+9 \%)\end{array}$ & 16,554 & $\begin{array}{l}20,191 \\
(+22 \%)\end{array}$ & $\begin{array}{l}21,606 \\
(+31 \%)\end{array}$ \\
\hline Diabetes mellitus $[13,14]^{\mathrm{c}}$ & $\begin{array}{l}4,100,000- \\
6,400,000\end{array}$ & $\begin{array}{l}4,900,000- \\
7,800,000 \\
(+22 \%)\end{array}$ & $\begin{array}{l}5,800,000- \\
7,800,000 \\
(+20-22 \%)\end{array}$ & $4,993-7,730$ & $\begin{array}{l}6,497- \\
10,056 \\
(+30 \%)\end{array}$ & $\begin{array}{l}7,185- \\
11,287 \\
(+44-46 \%)\end{array}$ \\
\hline Hypertension $[15]^{\mathrm{c}}$ & $34,800,000$ & $\begin{array}{l}37,900,000 \\
(+9 \%)\end{array}$ & $\begin{array}{l}35,500,000 \\
(+2 \%)\end{array}$ & 42,367 & $\begin{array}{l}49,035 \\
(+16 \%)\end{array}$ & $\begin{array}{l}51,591 \\
(+22 \%)\end{array}$ \\
\hline Chronic obstructive lung disease $[16]^{c}$ & $6,400,000$ & $\begin{array}{l}7,900,000 \\
(+23 \%)\end{array}$ & $\begin{array}{l}7,900,000 \\
(+23 \%)\end{array}$ & 7,829 & $\begin{array}{l}10,259 \\
(+31 \%)\end{array}$ & $\begin{array}{l}11,533 \\
(+47 \%)\end{array}$ \\
\hline Dialysis $[17]^{c}$ & 72,000 & $\begin{array}{l}84,800 \\
(+18 \%)\end{array}$ & $\begin{array}{l}85,300 \\
(+18 \%)\end{array}$ & 88 & $\begin{array}{l}110 \\
(+25 \%)\end{array}$ & $\begin{array}{l}124 \\
(+41 \%)\end{array}$ \\
\hline Dementia $[18]^{\mathrm{c}}$ & $31,100,000$ & $\begin{array}{l}1,600,000 \\
(+51 \%)\end{array}$ & $\begin{array}{l}2,200,000 \\
(+104 \%)\end{array}$ & 1,300 & $\begin{array}{l}2,092 \\
(+61 \%)\end{array}$ & $\begin{array}{l}3,175 \\
(+144 \%)\end{array}$ \\
\hline
\end{tabular}

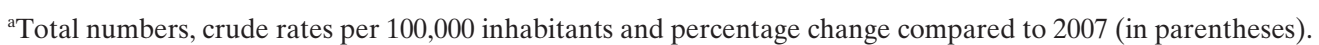

${ }^{\mathrm{b}}$ Prevalence is projected to the German population in 2007.

${ }^{c}$ Literature referred to the prevalence rate that is used for the projection.

expectancy, and a migration balance of 100,000 persons per year). Extracted sex- and age-specific disease rates (using 5-year age groups) were multiplied with the corresponding predicted population numbers for the years 2030 and 2050 giving (summed up) the expected number of cases for these years. For comparison we used case numbers and rates of 2007 based on the same calculation method as in the projection.

The continuously decreasing number of the German population was considered for the calculation of projected crude disease rates (per 100,000 persons). Additionally, we calculated percentage differences in absolute and relative incidence and prevalence figures (2030 and 2050 against 2007).

\section{Results}

Table 1 shows absolute numbers, crude rates and percentage change for the prevalence of selected diseases in Germany in the year 2007 and the projection to the years 2030 and 2050. Table 2 displays corresponding results for incidence data.

As an example the incidence of cancer (all sites, excluding non-melanoma skin cancer) is 461,000 cases in the year 2007 and will increase to 588,000 cases in the year $2050(+27 \%)$. The population-based crude rate of cancer will increase from 562 per 100,000 persons to 856 per 100,000 - a percentage increase in incidence rate of $+52 \%$ until 2050 .

The highest relative change until 2050 within the range of selected diseases is seen for dementia (prevalence $+144 \%$; table 1). While the risk of dementia is low in persons younger than 65 years $(<1 \%)$, it increases constantly up to $40 \%$ for persons older than 100 years. Incidence rates will rise from $349 / 100,000$ to $889 / 100,000$ in $2050(+155 \%$; table 2$)$. In 2007 about 1.1 million persons suffer from medium- or high-grade dementia. This number will be doubled until 2050. As an important consequence there will be an extensively increased need for long-term care. Similar to dementia the age-dependent macula degeneration (AMD), a typical disease of the elderly, will show a pronounced rise. The today's number of 875,000 persons with AMD will rise to 1.8 million persons in the year 2050. For hypertension only a small increase in relative disease rates is projected, but it has to be taken into account that prevalence is already on a very high level in our days. The risk of osteoporosis will increase from 10.1 to $15.1 \%$ $(+50 \%)$. Considering that two thirds of femoral neck fractures are caused by osteoporosis, the increase in osteoporosis could lead to more femur fractures. Incidence of femur fractures in Germany in 2007 is about 117,000 cases. The projection to the year 2050 leads to an increase of $88 \%$ (221,000 cases). For Hodgkin's lymphoma incident cases will decline by $-23 \%(-8 \%$ for rate), but non-Hodgkin's lymphoma and leukemia are expected to increase until 2050 by $45 \%$ and $55 \%$, respectively.

\section{Discussion}

The aim of this publication was to give a condensed description of projections concerning the future development of incidence and prevalence of selected diseases in the context of the demographic change in Germany. Unlike when calculating prognoses, no short- or long-term trends of the single diseases were considered for the presented projections. Our analyses were based on the status quo principle. It was assumed that sex- and age-specific disease risks would be con- 
Table 2. Incidence of selected diagnoses in Germany 2007,2030 und $2050^{\mathrm{a}}$

\begin{tabular}{|c|c|c|c|c|c|c|}
\hline \multirow[t]{2}{*}{ Diagnosis } & \multicolumn{3}{|c|}{ Absolute numbers (rounded) } & \multicolumn{3}{|c|}{ Relative numbers (per 100,000) } \\
\hline & $2007^{\mathrm{b}}$ & 2030 & 2050 & 2007 & 2030 & 2050 \\
\hline Femoral neck fracture $[19]^{\mathrm{c}}$ & 117,000 & $\begin{array}{l}166,000 \\
(+42 \%)\end{array}$ & $\begin{array}{l}221,000 \\
(+88 \%)\end{array}$ & 143 & $\begin{array}{l}215 \\
(+51 \%)\end{array}$ & $\begin{array}{l}321 \\
(+125 \%)\end{array}$ \\
\hline Myocardial infarction $[20]^{\mathrm{c}}$ & 313,000 & $\begin{array}{l}444,000 \\
(+42 \%)\end{array}$ & $\begin{array}{l}548,000 \\
(+75 \%)\end{array}$ & 381 & $\begin{array}{l}575 \\
(+51 \%)\end{array}$ & $\begin{array}{l}797 \\
(+109 \%)\end{array}$ \\
\hline Stroke $[21]^{\mathrm{c}}$ & 186,000 & $\begin{array}{l}255,000 \\
(+37 \%)\end{array}$ & $\begin{array}{l}301,000 \\
(+62 \%)\end{array}$ & 226 & $\begin{array}{l}330 \\
(+46 \%)\end{array}$ & $\begin{array}{l}438 \\
(+94 \%)\end{array}$ \\
\hline Implantation of pacemaker $[22]^{\mathrm{c}}$ & 100,000 & $\begin{array}{l}141,000 \\
(+41 \%)\end{array}$ & $\begin{array}{l}168,000 \\
(+68 \%)\end{array}$ & 122 & $\begin{array}{l}183 \\
(+50 \%)\end{array}$ & $\begin{array}{l}244 \\
(+100 \%)\end{array}$ \\
\hline $\begin{array}{l}\text { Cancer (all sites excluding non melanoma } \\
\text { skin cancer) }[23]^{c}\end{array}$ & 461,000 & $\begin{array}{l}580,000 \\
(+26 \%)\end{array}$ & $\begin{array}{l}588,000 \\
(+27 \%)\end{array}$ & 562 & $\begin{array}{l}752 \\
(+34 \%)\end{array}$ & $\begin{array}{l}856 \\
(+52 \%)\end{array}$ \\
\hline Breast cancer $[23]^{\mathrm{c}}$ & 59,000 & $\begin{array}{l}64,000 \\
(+9 \%)\end{array}$ & $\begin{array}{l}59,000 \\
(+1 \%)\end{array}$ & 140 & $\begin{array}{l}163 \\
(+16 \%)\end{array}$ & $\begin{array}{l}169 \\
(+20 \%)\end{array}$ \\
\hline Prostate cancer $[23]^{\mathrm{c}}$ & 63,000 & $\begin{array}{l}88,000 \\
(+39 \%)\end{array}$ & $\begin{array}{l}88,000 \\
(+39 \%)\end{array}$ & 157 & $\begin{array}{l}231 \\
(+47 \%)\end{array}$ & $\begin{array}{l}260 \\
(+66 \%)\end{array}$ \\
\hline Colorectal cancer $[23]^{\#}$ & 78,000 & $\begin{array}{l}102,000 \\
(+31 \%)\end{array}$ & $\begin{array}{l}109,000 \\
(+40 \%)\end{array}$ & 95 & $\begin{array}{l}133 \\
(+40 \%)\end{array}$ & $\begin{array}{l}158 \\
(+67 \%)\end{array}$ \\
\hline Lung cancer $[23]^{\mathrm{c}}$ & 49,000 & $\begin{array}{l}63,000 \\
(+28 \%)\end{array}$ & $\begin{array}{l}62,000 \\
(+26 \%)\end{array}$ & 60 & $\begin{array}{l}82 \\
(+36 \%)\end{array}$ & $\begin{array}{l}90 \\
(+51 \%)\end{array}$ \\
\hline Hodgkin lymphoma [23] & 2,000 & $\begin{array}{l}1,700 \\
(-13 \%)\end{array}$ & $\begin{array}{l}1,500 \\
(-23 \%)\end{array}$ & 2 & $\begin{array}{l}2 \\
(-7 \%)\end{array}$ & $\begin{array}{l}2 \\
(-8 \%)\end{array}$ \\
\hline Non-Hodgkin lymphoma [23] & 14,000 & $\begin{array}{l}16,000 \\
(+21 \%)\end{array}$ & $\begin{array}{l}16,000 \\
(+21 \%)\end{array}$ & 16 & $\begin{array}{l}21 \\
(+28 \%)\end{array}$ & $\begin{array}{l}24 \\
(+45 \%)\end{array}$ \\
\hline Leukemia [23] & 10,000 & $\begin{array}{l}12,000 \\
(+21 \%)\end{array}$ & $\begin{array}{l}12,000 \\
(+29 \%)\end{array}$ & 12 & $\begin{array}{l}15 \\
(+29 \%)\end{array}$ & $\begin{array}{l}18 \\
(+55 \%)\end{array}$ \\
\hline Dialysis $[17]^{\mathrm{c}}$ & 19,000 & $\begin{array}{l}22,800 \\
(+20 \%)\end{array}$ & $\begin{array}{l}23,200 \\
(+22 \%)\end{array}$ & 23 & $\begin{array}{l}30 \\
(+28 \%)\end{array}$ & $\begin{array}{l}34 \\
(+46 \%)\end{array}$ \\
\hline Dementia $[18]^{\mathrm{c}}$ & 290,000 & $\begin{array}{l}440,000 \\
(+53 \%)\end{array}$ & $\begin{array}{l}610,000 \\
(+113 \%)\end{array}$ & 349 & $\begin{array}{l}568 \\
(+63 \%)\end{array}$ & $\begin{array}{l}889 \\
(+155 \%)\end{array}$ \\
\hline
\end{tabular}

${ }^{a}$ Total numbers, crude rates per 100,000 inhabitants and percentage change compared to 2007 (in parentheses).

${ }^{\mathrm{b}}$ Prevalence is projected to the German population in 2007.

${ }^{c}$ Literature referred to the prevalence rate that is used for the projection.

stant over time. Only temporal population changes as predicted by official statistics were accounted for. Thus, presented results are a solely and direct effect of the demographic change, which has to be considered when interpreting the data. Preference was given to the method of projection rather than to the method of prognosis because trends of diseases depend on multivariable unknown factors that are hardly predictable and make computation of a valid prognosis difficult (for a deeper insight into prognoses and projections see [8]). For instance, future disease risks might be influenced by pharmaceutical innovations, medical technology progress, primary prevention, changing risk factors and social conditions as well as by political decisions. This has two implications for the interpretation of our disease projections. If disease risks will substantially decrease in the future our projections will be falsely high, if disease risks will increase within the next decades the projections will be falsely low. Despite of this limitation, projections based on the status quo method seem to be an appropriate approach to contribute at least crude peaces of information for future developments.
With the presented selection of medical conditions we tried to select common diseases with a public health impact - knowing that this selection is only a small sample (more examples for Germany are given in [8]). Aside from the public health impact our presented collection should also cover the aspect 'blood and transfusion'. It has to be mentioned that the final selection of diseases was limited by the availability of population-based disease data. Currently, up to date epidemiological information of many potentially interesting diseases in Germany are missing (especially when needed stratified by sex and age and for age groups older than 75 years).

For the interpretation and evaluation of the results it has to be considered that the projected absolute disease numbers are only half the truth. It is of utmost importance to take into account the relative figures, here expressed as numbers per 100,000 inhabitants. Whilst absolute numbers give an orientation for infrastructure needs (e.g. number of hospital beds, medical or nursing staff), the relative numbers reflect the burden of the disease at the population level. Even if absolute 
numbers stay stable over time or only a discrete increase is predicted, this implies a pronounced increase in disease burden in the shrinking German population.

Our results show that incidence and prevalence of widespread diseases will continuously rise until 2050, especially for cost-intensive diseases such as arthritis, dementia or cancer. On the other hand, the need of resources in obstetrics and pediatrics will lessen due to the declining number of births (data not shown).

The strong increase of the presented disease incidences and prevalences will also have implications for the field of transfusion medicine, particularly with regard to the supply with blood or blood components. The diagnosis 'femoral neck fracture' is a good example to give a picture of the dimension of the further needs of blood supply. In general this diagnosis is an indication for surgery where mostly a blood transfusion is needed. The population-based estimate gives more than a doubling of femoral neck fractures $(+125 \%)$. Hence an increase of a similar extent has to be expected for blood transfusions in this field. Another example is the use of blood in the oncological context. Especially in high-dose chemotherapy and therapy of leukemia and lymphoma, a high number of blood transfusions are needed. Using incidence of leukemia as an indicator for blood supply, there will be an increased demand of $55 \%$ until 2050 compared to 2007.
According to information of the Paul-Ehrlich-Institute, about 4.8 million blood donations were given in the year 2008 [9]. This equals a number of 5,800 blood samples per 100,000 inhabitants. Even if we assume a constant population-based blood donation rate, this number will decrease to about 4.0 million donations in 2050 due to the shrinking population. This development will be boosted by the declining 'younger' population $(<65$ years) who represents the age group of blood donors. In Germany blood donation is usually possible at the age of 18 to 68 years (first time donors $<60$ years). So it has to be expected that the amount of available blood will substantially decline while at the same time incidence and prevalence of relevant medical conditions and thus needed blood donations are expected to increase.

In conclusion the projected developments in demographic change and disease prevalence describe an extraordinary challenge for the German health care system and in particular for transfusion medicine. Therefore, it is high time to develop new concepts to meet these future demands and to ensure a high performance health care system.

\section{Disclosure}

The authors declared no conflict of interest.

\section{References}

1 Statistisches Bundesamt: Bevölkerung bis 2050, 11. koordinierte Bevölkerungsvorausberechnung. Wiesbaden, 2006.

2 Statistisches Bundesamt: Periodensterbetafeln für Deutschland. Allgemeine und abgekürzte Sterbetafeln. Wiesbaden, 2006.

3 Statistisches Bundesamt: Bevölkerung und Erwerbstätigkeit. Sterbetafel Deutschland 2005/07. Wiesbaden, 2008

4 Wiesner G, Grimm J, Bittner E: Schlaganfall: Prävalenz, Inzidenz, Trend, Ost-West-Vergleich Erste Ergebnisse aus dem Bundes-Gesundheitssurvey 1998. Gesundheitswesen 1999;61:79-84.

5 Thamm M: Blutdruck in Deutschland - Zustandsbeschreibung und Trends. Gesundheitswesen 1999; 61:90-93.

6 Wiesner G, Bittner E: Zur Inzidenz und Prävalenz von Mehrfachkrankheiten in Deutschland. Arbeitsmedizin, Sozialmedizin, Umweltmedizin 2005;40: 490-498.

7 Statistische Bundesamt: Ad-hoc-table: Krankheitskosten in Mio. $€$ für Deutschland. Gliederungsmerkmale: Jahre, Altersgruppen, Geschlecht für 2002 und 2006. www.gbe-bund.de (accessed March 18, 2010).

8 Peters E, Pritzkuleit R, Beske F, Katalinic A: Demographischer Wandel und Krankheitshäufigkeiten. Eine Projektion bis 2050. Bundesgesundheitsblatt 2010;(in print).

9 Paul Ehrlich Institut: Berichte nach \$21 Transfusionsgesetz (TFG). Gewinnung, Herstellung, Import, Export und Verbrauch 2008. www.pei.de/ nn_156154/DE/infos/21tfg/08-berichte/berichte-21node.html?_nnn = true $($ accessed March 18, 2010).
10 Friedman DS, O'Colmain BJ, Muñoz B, Tomany SC, McCarty C, de Jong PT, Nemesure B, Mitchell P, Kempen J; Eye Diseases Prevalence Research Group: Prevalence of age-related macular degeneration in the United States. Arch Ophthalmol 2004;122:564-572.

11 Häussler B, Gothe H, Mangiapane S, Glaeske G, Pientka L, Felsenberg D: Versorgung von Osteoporose-Patienten in Deutschland. Ergebnisse der BoneEVA Studie. Dtsch Ärztebl 2006; 103(39):2542-2548.

12 Robert Koch-Institut: Gesundheitsberichtserstattung des Bundes. Telefonischer Gesundheitssurvey des Robert Koch-Instituts. (2. Welle). Deskriptiver Endbericht. Berlin, 2006, S. 36.

13 Thefeld W: Prävalenz des Diabetes mellitus in der erwachsenen Bevölkerung Deutschlands. Gesundheitswesen 1999;61:85-89.

14. Hauner H, Koster I, von Ferber L: Prevalence of diabetes mellitus in Germany 1998-2001. Secondary data analysis of a health insurance sample of the AOK in Hesse/KV in Hesse. Dtsch Med Wochenschr 2003;128:2632-2637.

15 Robert Koch-Institut: Hypertonie. Gesundheitsberichterstattung des Bundes 2008;43:11.

16 Schirnhofer L, Lamprecht B, Vollmer WM, Allison MJ, Studnicka M, Jensen RL, Buist AS: COPD prevalence in Salzburg, Austria: results from the Burden of Obstructive Lung Disease (BOLD) Study. Chest 2007;131(1):29-36
17 Frei U, Schober-Halstenberg HJ: Nierenersatztherapie in Deutschland. Bericht über Dialysebehandlung und Nierentransplantation in Deutschland 2006/2007. Quasi-Niere, 2008.

18 Ziegler U, Doblhammer G: Prävalenz und Inzidenz von Demenz in Deutschland - Eine Studie auf Basis von Daten der gesetzlichen Krankenversicherungen von 2002. Gesundheitswesen 2009;71: 281-290.

19 Abendroth K, Defèr A: Neue Aspekte zur Epidemiologie der Hüftfrakturen in Deutschland. MedReport 2009;6(33):6. www.schroeders-agentur.de/ medpdf09/MedReport06_2009.pdf (accessed March 18, 2010).

20 Robert Koch-Institut: Gesundheit in Deutschland, Berlin, 2006, S. 25.

21 Kolominsky-Rabas PL, Sarti C, Heuschmann PU, Graf C, Siemonsen S, Neundoerfer B, Katalinic A, Lang E, Gassmann KG, von Stockert TR: A prospective community-based study of stroke in Germany - The Erlangen Stroke Project (ESPro) incidence and case fatality at 1,3 , and 12 months. Stroke 1998;29(12):2501-2506.

22 Markewitz A: Jahresbericht 2006 des Deutschen Herzschrittmacher-Registers. Herzschrittmacherther Elektrophysiol 2008;19(4):195-223.

23. Robert Koch-Institut, Gesellschaft der epidemiologischen Krebsregister in Deutschland e.V.: Krebs in Deutschland 2003-2004. Häufigkeiten und Trends. 6th revised ed. Berlin, 2008. 